\title{
ANALISIS KESESUAIAN PERAIRAN UNTUK PENGEMBANGAN LOKASI BUDIDAYA RUMPUT LAUT (Euchema cottonii)DI PERAIRAN LHOK BUBON KECAMATAN SAMATIGA KABUPATEN ACEH BARAT
}

\section{WATER SUITABILITY ANALYSIS FOR SEAWEED (Euchema cottonii) CULTIVATION DEVELOPMENT AREA IN LHOK BUBON SEASHORE SAMATIGA DISTRICT WEST ACEH REGENCY}

\author{
Fitria Rahmayanti ${ }^{1 *}$, Farah Diana ${ }^{1}$, Ika Kusumawati ${ }^{2}$ \\ ${ }^{1}$ Program Studi Akuakultur, Fakultas Perikanan dan Ilmu Kelautan, Universitas Teuku Umar, Aceh Barat \\ ${ }^{2}$ Program Studi Akuakultur, Fakultas Perikanan dan Ilmu Kelautan, Universitas Teuku Umar, Aceh Barat \\ *Korespondensi: rea_syakurah@yahoo.co.id
}

\begin{abstract}
ABSTRAK
Rumput laut merupakan salah satu komoditas budidaya laut yang memiliki nilai ekonomis tinggi. Upaya mengembangkan budidaya rumput laut diperlukan untuk meningkatkan produksi serta meningkatkan pendapatan masyarakat pesisir. Keberhasilan budidaya rumput laut sangat dipengaruhi oleh faktor kualitas perairan yang mendukung dan sesuai untuk pertumbuhannya. Penelitian ini bertujuan untuk menganalisis tingkat kesesuaian perairan Lhok Bubon untuk pengembangan budidaya rumput laut Euchema cottonii. Parameter fisika dan kimia yang diukur selama penelitian adalah kecerahan air, kedalaman, ketinggian gelombang, kecepatan arus, suhu, $\mathrm{pH}$ dan salinitas. Hasil penelitian menunjukkan perairan Lhok Bubon termasuk dalam kategori tidak sesuai hingga kurang sesuai untuk dikembangkan sebagai lokasi budidaya rumput laut.
\end{abstract}

Kata kunci: Kualitas air, Lhok Bubon, rumput laut.

\begin{abstract}
Seaweed is one of marine aquaculture commodities with high economic value. Seaweed cultivation is needed as the development effort to increase the production and coastal communities income. The success of seaweed cultivation is strongly influenced by water quality factors appropriate for its growth. This research was conducted in September 2016 at four differences location in Lhok Bubon seashore. The purpose of this study was to analyze the level of Lhok Bubon water suitability as seaweed cultivation development. The physical and chemical parameters measurement during this study were water current velocity, brightness, depth, wave height, temperature, $\mathrm{pH}$ and salinity. The result showed that Lhok Bubon seashore are categorized as less suitable to not suitable for seaweed cultivation location.
\end{abstract}

Keywords: Lhok Bubon, seaweed, water quality.

\footnotetext{
${ }^{1}$ Fakultas Perikanan dan Ilmu Kelautan, Universitas Teuku Umar

Korespondensi: Jurusan Akuakultur, Fakultas Perikanan dan Ilmu Kelautan, Universitas Teuku Umar, Kampus UTU Meulaboh, Alue Peunyareng 23615, HP: +62 85297805010, email: rea_syakurah@yahoo.co.id
} 



\section{PENDAHULUAN}

Rumput laut merupakan salah satu komoditas budidaya laut yang memiliki nilai ekonomis tinggi. Pemanfaatan rumput laut yang semakin beragam baik dalam industri makanan, minuman, kosmetik maupun obatobatan menyebabkan kebutuhannya semakin meningkat. Menurut Atmadja et al. (1996), pada awal 1980 perkembangan permintaan rumput laut di dunia meningkat seiring dengan peningkatan pemakaian rumput laut untuk berbagai keperluan antara lain di bidang industri, makanan, tekstil, kertas, cat, kosmetika, dan farmasi (obat-obatan).

Masyarakat yang tinggal dekat dengan Perairan Lhok Bubon Kabupaten Aceh Barat diketahui belum memanfaatkan perairan tersebut dengan maksimal untuk melakukan kegiatan budidaya. Padahal jika masyarakat mampu membaca potensi yang ada yaitu dengan membudidayakan rumput laut sebagai komoditas budidaya maka tidak dipungkiri perekonomian masyarakat akan meningkat. Menurut Anggadiredja et al.(2006), usaha budidaya rumput laut yang dilakukan secara intensif akan memberikan hasil yang baik, yaitu meningkatnya produksi dan ekspor rumput laut.

Keberhasilan budidaya rumput laut sangat dipengaruhi oleh faktor kualitas perairan yang mendukung dan sesuai untuk pertumbuhannya. Menurut Priono (2013), faktor-faktor yang perlu diperhatikan dalam budidaya rumput laut adalah: (1) pemilihan lokasi yang memenuhi persyaratan bagi jenis rumput laut yang akan dibudidayakan. Hal ini perlu karena ada perlakukan yang berbeda untuk tiap jenis rumput laut, (2) pemilihan atau seleksi bibit, penyediaan bibit, dan cara pembibitan yang tepat, (3) metode budidaya yang tepat, (4) pemeliharaan selama musim tanam, dan (5) metode panen dan perlakuan pascapanen yang benar.

Selanjutnya Lobban dan Harrison (1997) menyatakan bahwa pemilihan lokasi yang tepat merupakan faktor yang penting dalam menentukan kelayakan usaha budidaya rumput laut. Faktor utama keberhasilan kegiatan budidaya rumput laut adalah pemilihan lokasi yang tepat. Di antara faktor lingkungan tersebut adalah ketersediaan cahaya, suhu, salinitas, arus dan ketersediaan nutrient.

Salah satu kesalahan dalam pengembangan budidaya adalah lingkungan perairan yang tidak cocok. Penentuan lokasi pengembangan budidaya rumput laut lebih berdasarkan pada feeling atau trial and error (Hartoko dan Helmi 2004). Oleh karena itu, informasi tentang kelayakan lokasi budidaya rumput laut sangat diperlukan demi keberhasilan pengembangan budidaya rumput laut di suatu perairan.

Penelitian ini bertujuan untuk menganalisis tingkat kesesuaian perairan Lhok Bubon untuk pengembangan budidaya rumput laut Euchema cottonii. Hasil dari penelitian ini diharapkan dapat memberikan gambaran awal untuk pengembangan perairan sebagai lokasi budidaya rumput laut.

\section{METODE PENELITIAN}

Penelitian ini dilaksanakan di Perairan Lhok Bubon Kecamatan Sama Tiga Kabupaten Aceh Barat. Pengumpulan data dilakukan pada bulan September 2016. Metode penelitian yang digunakan adalah metode survei. Lokasi titik pengamatan mengacu pada fisiografis lokasi dengan mengambil sampel di lokasi yang dapat mewakili kondisi keseluruhan fisika kimia oseanografi lapangan. Pada penelitian ini stasiun yang digunakan berjumlah 4 stasiun. Parameter yang diukur adalah terhadap kedalaman, ketinggian gelombang, suhu, kecerahan, kecepatan arus, salinitas, dan $\mathrm{pH}$.

\section{Analisa Data}

Data yang diperoleh ditabulasi ke dalam tabel kemudian dicocokkan dengan kriteria kesesuaian lahan untuk budidaya rumput laut yang dimodifikasi dari Neksidin et al. (2013). 
Tabel 1. Kriteria Kesesuaian Lahan untuk Budidaya Rumput Laut

\begin{tabular}{|c|c|c|c|c|}
\hline No. & Kriteria & Kelas & Skor & Bobot \\
\hline \multirow{3}{*}{1} & \multirow{3}{*}{ Kecerahan Air (m) } & $>5$ & 3 & \multirow{3}{*}{2} \\
\hline & & $1.5-4$ & 2 & \\
\hline & & $<1.5$ & 1 & \\
\hline \multirow{3}{*}{2} & \multirow{3}{*}{ Tinggi Gelombang (cm) } & $0-25$ & 3 & \multirow{3}{*}{2} \\
\hline & & $25-50$ & 2 & \\
\hline & & $>50$ & 1 & \\
\hline \multirow{3}{*}{3} & \multirow{3}{*}{ Kedalaman (m) } & $5-10$ & 3 & \multirow{3}{*}{2} \\
\hline & & $1-4$ atau $11-15$ & 2 & \\
\hline & & $<1$ atau $>15$ & 1 & \\
\hline \multirow{3}{*}{4} & \multirow{3}{*}{ Kecepatan Arus (cm/dtk) } & $20-30$ & 3 & \multirow{3}{*}{2} \\
\hline & & $10-19$ atau $31-40$ & 2 & \\
\hline & & $<10$ atau $>40$ & 1 & \\
\hline \multirow{3}{*}{5} & \multirow{3}{*}{ Suhu $\left({ }^{\circ} \mathrm{C}\right)$} & $27-30$ & 3 & \multirow{3}{*}{1} \\
\hline & & $20-26$ atau $31-36$ & 2 & \\
\hline & & $<20$ atau $>36$ & 1 & \\
\hline \multirow{3}{*}{6} & \multirow{3}{*}{$\mathrm{pH}$} & $6.5-8.5$ & 3 & \multirow{3}{*}{1} \\
\hline & & 5-6.4 atau 8.6-9 & 2 & \\
\hline & & $<5$ atau $>9$ & 1 & \\
\hline \multirow{3}{*}{7} & \multirow{3}{*}{ Salinitas (ppt) } & $28-34$ & 3 & \multirow{3}{*}{1} \\
\hline & & $18-27$ atau $35-37$ & 2 & \\
\hline & & $<18$ atau $>37$ & 1 & \\
\hline
\end{tabular}

Sumber: Dimodifikasi dari Neksidin et al. (2013)

Tabel 2. Kriteria Kesesuaian Lahan

\begin{tabular}{ccc}
\hline Nilai (skor) & Kriteria & Kode \\
\hline $34-45$ & Sesuai & S \\
$23-33$ & Kurang Sesuai & KS \\
$<23$ & Tidak Sesuai & TS \\
\hline
\end{tabular}

Sumber: Dimodifikasi dari Neksidin et al. (2013)

\section{HASIL DAN PEMBAHASAN}

\section{Pengamatan Kualitas Air}

Lokasi budidaya rumput laut menjadi faktor pertama yang harus diperhatikan dan merupakan faktor penentu berhasil tidaknya usaha budidaya yang dilakukan. Kesalahan dalam pemilihan lokasi budidaya rumput laut akan sangat mempengaruhi hasil dan mutu rumput laut (Hidayat, 1994). Hasil pengukuran kualitas air selama penelitian pada perairan Lhok Bubon untuk budidaya rumput laut pada masing-masing stasiun menunjukkan tingkatan yang berbeda-beda namun tidak terlalu berbeda jauh. Hasil parameter kualitas perairan yang dilakukan di perairan Lhok Bubon dapat dilihat pada Tabel 3. 
Tabel 3. Parameter kualitas air selama penelitian di perairan Lhok Bubon

\begin{tabular}{clccccc}
\hline \multirow{2}{*}{ No } & \multirow{2}{*}{ Parameter } & \multicolumn{4}{c}{ Stasiun } \\
\cline { 3 - 6 } & & $\mathbf{1}$ & $\mathbf{2}$ & $\mathbf{3}$ & $\mathbf{4}$ \\
\hline 1 & Kecerahan Air (m) & 1.5 & 1.3 & 1.4 & 1.5 \\
2 & Ketinggian Gelombang (m) & 0.5 & 0.35 & 0.46 & 0.48 \\
3 & Kedalaman (m) & 2 & 2.7 & 3 & 2.1 \\
4 & Kecepatan Arus (cm/dtk) & 19 & 12 & 17 & 17 \\
5 & Suhu $\left({ }^{\circ} \mathrm{C}\right)$ & 30.2 & 29.5 & 29.3 & 30.4 \\
6 & pH & 7.3 & 7.9 & 7.8 & 7.9 \\
7 & Salinitas (ppt) & 29.4 & 35 & 35 & 34.8 \\
\hline
\end{tabular}

Nilai Kesesuaian Perairan Budidaya Rumput Laut

Nilai hasil evaluasi setiap parameter diperoleh dari hasil pengukuran kualitas air dengan tiga kali pengulangan setiap stasiunnya. Hasil pengamatan kualitas air yang didapatkan di lapangan kemudian dicocokkan dengan kriteria kesesuaian lahan untuk budidaya rumput laut yang dimodifikasi dari Neksidin et al. (2013). Hasil analisis kesesuaian lokasi budidaya rumput laut di Perairan Lhok Bubon pada setiap stasiun dapat dilihat pada tabel berikut ini.

Tabel 4. Analisis kesesuaian lokasi budidaya rumput laut stasiun 1

\begin{tabular}{clcccc}
\hline No & \multicolumn{1}{c}{ Parameter } & $\begin{array}{c}\text { Hasil } \\
\text { Pengamatan }\end{array}$ & Bobot & Skor & Nilai \\
\hline 1 & Kecerahan Air $(\mathrm{m})$ & 1.5 & 2 & 2 & 4 \\
2 & Ketinggian Gelombang $(\mathrm{cm})$ & 0.5 & 2 & 2 & 4 \\
3 & Kedalaman (m) & 2 & 2 & 2 & 4 \\
4 & Kecepatan Arus (cm/dtk) & 19 & 2 & 2 & 4 \\
5 & Suhu $\left({ }^{\circ} \mathrm{C}\right)$ & 30.2 & 1 & 3 & 3 \\
6 & pH & 7.3 & 1 & 3 & 3 \\
7 & Salinitas (ppt) & 29.4 & 1 & 3 & 3 \\
\hline & TOTAL & & & $\mathbf{2 5}$
\end{tabular}

Tabel 5. Analisis kesesuaian lokasi budidaya rumput laut stasiun 2

\begin{tabular}{llcccc}
\hline No & \multicolumn{1}{c}{ Parameter } & $\begin{array}{c}\text { Hasil } \\
\text { Pengamatan }\end{array}$ & Bobot & Skor & Nilai \\
\hline 1 & Kecerahan Air $(\mathrm{m})$ & 1.3 & 2 & 1 & 2 \\
2 & Ketinggian Gelombang (m) & 0.35 & 2 & 2 & 4 \\
3 & Kedalaman (m) & 2.7 & 2 & 2 & 4 \\
4 & Kecepatan Arus (cm/dtk) & 12 & 2 & 2 & 4 \\
5 & Suhu $\left({ }^{\circ} \mathrm{C}\right)$ & 29.5 & 1 & 3 & 3 \\
6 & pH & 7.9 & 1 & 3 & 3 \\
7 & Salinitas (ppt) & 35 & 1 & 2 & 2 \\
\hline & TOTAL & & & & $\mathbf{2 2}$ \\
\hline
\end{tabular}


Tabel 6. Analisis kesesuaian lokasi budidaya rumput laut stasiun 3

\begin{tabular}{clcccc}
\hline No & \multicolumn{1}{c}{ Parameter } & $\begin{array}{c}\text { Hasil } \\
\text { Pengamatan }\end{array}$ & Bobot & Skor & Nilai \\
\hline 1 & Kecerahan Air (m) & 1.4 & 2 & 1 & 2 \\
2 & Ketinggian Gelombang (m) & 0.46 & 2 & 2 & 4 \\
3 & Kedalaman (m) & 3 & 2 & 2 & 4 \\
4 & Kecepatan Arus (cm/dtk) & 17 & 2 & 2 & 4 \\
5 & Suhu $\left({ }^{\circ} \mathrm{C}\right)$ & 29.3 & 1 & 3 & 3 \\
6 & pH & 7.8 & 1 & 3 & 3 \\
7 & Salinitas (ppt) & 35 & 1 & 2 & 2 \\
\hline & TOTAL & & & $\mathbf{2 2}$ \\
\hline
\end{tabular}

Tabel 7. Analisis kesesuaian lokasi budidaya rumput laut stasiun 4

\begin{tabular}{clcccc}
\hline No & \multicolumn{1}{c}{ Parameter } & $\begin{array}{c}\text { Hasil } \\
\text { Pengamatan }\end{array}$ & Bobot & Skor & Nilai \\
\hline 1 & Kecerahan Air (m) & 1.5 & 2 & 2 & 4 \\
2 & Ketinggian Gelombang (m) & 0.48 & 2 & 2 & 4 \\
3 & Kedalaman (m) & 2.1 & 2 & 2 & 4 \\
4 & Kecepatan Arus (cm/dtk) & 17 & 2 & 2 & 4 \\
5 & Suhu $\left({ }^{\circ} \mathrm{C}\right)$ & 30.4 & 1 & 3 & 3 \\
6 & pH & 7.9 & 1 & 3 & 3 \\
7 & Salinitas (ppt) & 34.8 & 1 & 3 & 3 \\
\hline & & TOTAL & & & $\mathbf{2 5}$ \\
\hline
\end{tabular}

Nilai parameter kualitas air di perairan Lhok Bubon menunjukkan kriteria yang kurang sesuai hingga tidak sesuai untuk pengembangan budidaya rumput laut menurut kriteria kesuaian lahan untuk budidaya rumput laut Neksidin et al. (2013). Parameter kualitas air dari empat stasiun, dua stasiun diketahui kurang sesuai untuk budidaya rumput laut dan dua stasiun diketahui tidak sesuai untuk budidaya rumput laut.

Parameter kualitas air yang berada pada kategori kurang sesuai hingga tidak sesuai di perairan Lhok Bubon adalah parameter kecerahan air. Hutabarat (2000) mengatakan bahwa, cahaya akan semakin berkurang intensitasnya seiring dengan makin besar kedalaman. Pendugaan lain adalah adanya perbedaan waktu pengamatan yang dilakukan. Effendi (2003) mengatakan bahwa pemantulan cahaya mempunyai intensitas yang bervariasi menurut sudut datang cahaya.

Selain itu Puslitbangkan (1991) dalam Astriwayana (2010) menyatakan bahwa kondisi air yang jernih dengan tingkat transparansi tidak kurang dari $5 \mathrm{~m}$ cukup baik untuk pertumbuhan rumput laut. Tingkat kecerahan yang tinggi diperlukan dalam budidaya rumput laut, hal ini dimaksud agar cahaya penetrasi dapat masuk ke dalam air. Intensitas sinar matahari yang di terima secara sempurna oleh thallus merupakan faktor utama dalam proses fotosintesis.

Keterlindungan suatu areal budidaya rumput laut perlu dipertimbangkan, sebab kerusakan secara fisik sarana budidaya maupun rumput laut dari pengaruh angin dan gelombang yang besar, maka diperlukan lokasi yang terlindung. Lokasi yang terlindung biasanya terletak di perairan teluk atau perairan terbuka tetapi terlindung oleh adanya penghalang atau pulau didepannya (Sunaryat, 2004).

Sedangkan yang masuk dalam kategori kurang sesuai adalah parameter ketinggian gelombang, kedalaman dan kecepatan arus. Ketinggian gelombang di lokasi penelitian 
termasuk besar karena tiga stasiun dari total empat stasiun memiliki gelombang lebih dari $40 \mathrm{~cm}$ sehingga kondisi ini. Aslan (1991) mengemukakan bahwa untuk kegiatan budidaya rumput laut tinggi ombak tidak lebih dari $40 \mathrm{~cm}$. Ombak yang terlalu besar dapat menyebabkan kekeruhan perairan sehingga dapat menghambat fotosintesis, selain itu ombak yang besar dapat menyulitkan tanaman untuk menyerap nutrisi sehingga dapat menghambat pertumbuhan.

Menurut Priono (2013), beberapa persyaratan yang harus diperhatikan adalah perairan cukup tenang, terlindungi dari pengaruh angin dan ombak, tersedianya rumput laut alami setempat (indikator), kedalaman tidak boleh kurang dari dua kaki (sekitar $60 \mathrm{~cm}$ ) pada saat surut terendah dan tidak lebih dari tujuh kaki (sekitar $210 \mathrm{~cm}$ ) pada saat pasang tertinggi. Selain itu, juga harus didukung dasar perairan (tipe dan sifat substrat) yang digunakan, dasar perairan sedikit berlumpur atau berpasir, perairan subur atau kurang subur (plankton banyak atau sedikit).

Menurut Afrianto (1987), arus dapat membawa zat makanan bagi rumput laut serta dapat membersihkan kotoran yang menempel, kecepatan arus jangan melebihi $50 \mathrm{~cm}$ setiap detiknya karena dapat merusak tanaman, arus yang kuat dapat menyebabkan kekeruhan hingga menghalangi fotosintesis dan juga menimbulkan kesulitan pada saat penanaman, pemeliharaan maupun pemanenan rumput laut.

Selama pengamatan, perairan Lhok Bubon diketahui memiliki kondisi substrat karang berpasir dan sedikit berlumpur. Anonim (2005) menyatakan bahwa pasir yang tercampur patahan karang merupakan dasar perairan yang ideal, hal ini sangat berhubungan dengan sediaan nutrien berupa fosfat yang berasal dari bebatuan tersebut. Priono (2013) menjelaskan bahwa keadaan substrat tersebut cukup baik untuk budidaya rumput laut.

Tingkat kecerahan di lokasi ini tidak sesuai untuk budidaya rumput laut disebabkan karena lokasi ini dipengaruhi oleh gelombang dan aktivitas masyarakat di lokasi tersebut. Lokasi ini digunakan oleh masyarakat untuk menambatkan perahu nelayan sehingga terjadi pengadukan massa air yang mengakibatkan naiknya substrat dasar perairan yang sedikit berlumpur.

Parameter suhu, $\mathrm{pH}$ dan salinitas di perairan Lhok Bubon termasuk dalam kategori sesuai untuk pengembangan budidaya rumput laut. Hal ini sesuai dengan pernyataan Aslan (1991), salinitas yang cocok untuk budidaya rumput laut berkisar antara 30 - 37 ppt, suhu $27-30^{\circ} \mathrm{C}$ dan $\mathrm{pH}$ 7.0-8.5. Berdasarkan Kep.Men.02/MenKLH/I/1988, $\mathrm{pH}$ untuk budidaya rumput laut yang diperbolehkan berada pada kisaran 6-9, kemudian $\mathrm{pH}$ yang diinginkan untuk budidaya rumput laut berkisar antara 6,5-8,5.

\section{KESIMPULAN}

Berdasarkan dari hasil analisis kesesuaian perairan untuk lokasi budidaya rumput laut Eucheuma cottonii di perairan Lhok Bubon dapat disimpulkan bahwa parameter kualitas perairan tersebut pada bulan September berada pada kisaran tidak sesuai sampai kurang sesuai.

\section{DAFTAR PUSTAKA}

Anggadiredja JT, Zatnika A, Purwoto H, dan Istini S. 2008. Rumput Laut, Pembudidayaan, Pengolahan dan Pemasaran Komoditas Perikanan Potensial. Jakarta. Penebar Swadaya.

Anonim. 2005. Profil Rumput Laut Indonesia. Jakarta. Direktorat Jendral Perikanan Budidaya Departemen Kelautan dan Perikanan.

Aslan L.M. 1991. Budidaya Rumput Laut. Yogyakarta. Penerbit Kanisius.

Astriwana. 2010. Peran Perendaman dengan Air Tawar dalam Menekan Penyakit Pada Budidaya Rumput Laut Kappaphycus alvarezii Dotty di Perairan Semak Daun, Kepulauan Seribu, Jakarta. Skripsi. Bogor. Fakultas Perikanan dan Ilmu Kelautan Institut Pertanian Bogor. 
Atmadja WS. 1996. Pengenalan Jenis Algae Merah. Dalam: Pengenalan Jenis- Jenis Rumput Laut Indonesia. Jakarta. Pusat Penelitian dan Pengembangan Oseanologi, Lembaga Ilmu Pengetahuan Indonesia.

Lobban, C.S., Harrison, P.J. 1997. Seaweed Ecology and Physiology. Cambridge. Cambridge University Press.

Effendi H. 2003. Telaah Kualitas Air Bagi Pengolahan Sumberdaya Hayati Lingkungan Perairan. Yogyakarta. Kanisius.

Hidayat A. 1994. Budidaya Rumput Laut. Surabaya. Penerbit Usaha Nasional.

Hutabarat S. 2000. Peranan Kondisi Oceanografi terhadap Perubahan Iklim, Produktivitas dan Distribusi Biota Laut. Semarang. UNDIP.
Neksidin, Pangerang UK dan Emiyarti. 2013. Studi Kualitas Air untuk Budidaya Rumput Laut (Kappaphycus alvarezii) di Perairan Teluk Kolono Kabupaten Konawe Selatan. Jurnal Mina Laut Indonesia 3: 3.

Nybakken JW. 1992. Biologi Laut,Sesuatu Pendekatan Ekologis. Jakarta. Penerbit PT. Gramedia Pustaka Utama.

Priono B. 2013. Budidaya Rumput Laut dalam Upaya Peningkatan Industrialisasi Perikanan. Media Akuakultur 8: 1-8.

Sunaryat. 2004. Pemilihan Lokasi Budidaya Rumput Laut. Makalah Pelatihan INBUDKAN Budidaya Kerapu dan Rumput Laut 24 s/d 29 Mei 2009 di Balai Budidaya Laut. Lampung. 